\title{
Parohia, mediu de vindecare a creștinilor prin harul lui Hristos
}

\section{Petru Ovidiu BĂGĂCIAN}

Abstract: This study analyzes the parish as an environment for healing of Christians by uniting them with Jesus Christ and the communion with the sanctifying grace of the Holy Spirit. The primary role of this therapeutic act plays the Mystery of Holy Unction. We are talking about both bodily and spiritual healing, which is reflected in indissoluble relationship between Orthodoxy and orthopraxis. Finally, it is remembered the role of cleansing, healing and sanctifying grace of the Holy Spirit, which makes the parish - "local church" - especially a "spiritual hospital" (G. Metallinos).

Abstract. În acest studiu este analizată parohia ca mediu de vindecare a creștinilor prin unirea cu Iisus Hristos și împărtăşirea cu harul sfințitor al Duhului Sfânt. Rolul primordial al acestui act terapeutic îl are Taina Sfântului Maslu. Vorbim despre o vindecare deopotrivă trupească și sufletească, în care se concretizează relația indisolubilă dintre ortodoxie și ortopraxie. În final este reamintit rolul curățitor, vindecător și sfințitor al harului Duhului Sfânt, care face din parohie - „biserica locală” - mai ales un „spital duhovnicesc” (G. Metallinos).

Keywords: parish, grace, healing, Mysteries, Unction, pastoral. 


\section{Introducere}

Într-o încercare de înnoire a înţelegerii parohiei în teologia de astăzi, mitropolitul Emilianos Timiadis scria despre dificultăţile care au apărut în parcursul istoriei: „Schimbarea unei atitudini de obstinaţie nu a fost nici o dată uşoară. Acţiunile înnoitoare întâlnesc deseori o rezistenţă enormă. Deşi din punct de vedere ecclesiologic o parohie face parte din Biserica universală a lui Hristos, totuşi, ea este constituită dintr-o comunitate de oameni, bărbaţi şi femei, care se luptă cu piedici şi greşeli, şi care se împotrivesc deseori să înainteze mai departe pe calea creştină şi să se lase puşi la încercare. Undeva pe traseu progresul a fost oprit, iar parohia ne apare ca fiind statică şi alcătuită din parohieni egoişti”". Într-adevăr, acest egoism care, din nefericire, tinde să predomine în societatea (post)modernă a consumerismului, are grave repercusiuni atât la nivel individual, cât şi comunitar. Este principalul motiv care ne determină să reanalizăm funcția parohiei ca „,celulă” primară a Bisericii, sau, altfel spus, ca mediu în care se realizează unirea concretă cu Mântuitorul nostru Iisus Hristos și împărtăşirea cu harul sfințitor al Duhului Sfânt.

În studiul de față dorim să evidențiem rolul parohiei de mediu terapeutic, deopotrivă pentru bolile trupești și sufletești, aspect fundamental ce demonstrează încă o dată dimensiunea universală a misiunii creștine. De ce aceasta? Fiindcă nu există om care, în cursul existenţei sale, să nu fi avut de-a face cu boala. Aceasta este inevitabil legată de condiţia umană. Nici un organism nu este perfect sănătos. Sănătatea nu este altceva decât un echilibru provizoriu între forțele vieţii şi alte forţe care i se opun, cele dintâi neavând decât o fragilă supremaţie. Chiar atunci când ne credem deplin sănătoşi, boala se află deja în noi şi va fi de ajuns să slăbească unul sau altul dintre mijloacele

\footnotetext{
${ }^{1}$ Mitropolit Emilianos Timiadis, Preot, parohie, înnoire. Noțiuni și orientări pentru teologia și practica pastorală, trad. Paul Brusanowski, Bucuresti, Edit. Sophia, 2001, p. 5.
} 
noastre de apărare pentru ca ea să apară, într-o formă sau alta”2. Lucrarea mântuitoare a lui Iisus Hristos a vizat tocmai să restaureaze relația adecvată dintre Dumnezeu și om, iar prin intermediul acestuia din urmă cu întreaga creație - o relaţie pe care păcatul, boala și moartea o mutilaseră. La rândul lor, încă de la începutul Bisericii, „urmând cu credincioșie exemplul dat de Hristos, de Apostoli și sfinții Săi, întotdeauna creștinii și-au desfășurat eforturile pentru a-i îngriji și a-i vindeca pe oamenii bolnavi, recurgând fie la terapeutici specific religioase, fie la medicina profană, căreia însă ei i-au dat un sens nou, duhovnicesc"3.

Printre aceste ,terapeutici specific religioase” un rol primordial îl ocupă în cadrul Bisericii Ortodoxe Taina Sfântului Maslu.

\section{Parohia și Sfântul Maslu}

Ca și în cazul celorlalte Taine ale Bisericii, legătura dintre aspectul teoretic și cel practic, între partea văzută și cea nevăzută a Maslului este indisolubilă. În această Taină un rol primordial îl au preoții, iar pentru ca lucrarea lor să fie eficace, este necesară o curățire a lor din punct de vedere duhonicesc. Pe de altă parte, Hristos Însuşi este „Doctorul sufletelor şi al trupurilor”, iar săvârşitorul văzut al Tainei doar o icoană a Lui. Vindecarea survine ca un efect al harului divin necreat, nu al capacităţilor umane - fie el oricât de ,desăvârşit” - ale preotului.

Epistola Sfântului Iacov (capitolul 5) atestă dimensiunea eclesială a Maslului: atunci când este cineva bolnav, toți prezbiterii trebuie să vină la el. Altfel spus, întreaga Biserică trebuie să se adune în jurul celui aflat în suferință (numărul șapte, decisiv pentru ritualul

\footnotetext{
${ }^{2}$ Jean-Claude Larchet, Teologia bolii, trad. Vasile Mihoc, Sibiu, Editura Oastea Domnului, 1997, p. 7.

${ }^{3}$ Ibidem, p. 86.
} 
și semnificaţia Tainei Maslului, exprimă chiar deplinătatea): ,ungerea bolnavilor, săvârșită în biserică (atunci când este posibil) și de către Biserică (cu participarea atât a clericilor cât și a credincioșilor care exprimă prezența Bisericii), țintește tocmai reintegrarea bolnavului în comunitate (în Biserică). Fie este adus bolnavul la biserică, fie Biserica merge acolo unde este bolnavul. În orice caz, Biserica, în calitatea ei de comunitate, stă alături de bolnav atunci când acesta se află în suferință, reintegrându-l în trupul lui Hristos. Acesta este unul din motivele pentru care slujba este atât de lungă - odinioară dura o săptămână, iar acum durează câteva ore. Slujba străbate prin izolare (s.n.), căci Hristos și Biserica stau alături de bolnav în acest moment critic al vieții sale - pe care fiecare om va trebui să-l înfrunte într-o bună zi!"’4.

Aici accentul este pus pe co-slujirea preoților cu laicii: întradevăr, Paul Meyendorff avea dreptate atunci când vorbea despre slujirea comunitară eclezială, ,cu participarea atât a clericilor cât și a credincioșilor care exprimă prezența Bisericii”. Întregul trup suferă atunci când unul dintre mădularele sale se îmbolnăvește și suferă (I Cor. 12, 26). De aici și co-responsabilitatea întregului corp eclezial clerici și laici deopotrivă.

Semnificaţia profundă a rugăciunii „Tatăl nostru” este aceea că, alături de simbolul Bisericii ca Trup al lui Hristos, Noul Testament a impus imaginea Bisericii ca o familie. În Taina Maslului ceea ce rămâne demn de interes pentru noi este prezența comunității alături de cel bolnav un timp cât mai îndelungat. Este o realitate că omul contemporan evită ,să dea ochii” cu suferința. Azilele sunt din ce în ce mai pline de oameni bătrâni și suferinzi, priviți ca un ,balast” chiar și de către cei mai apropiați din familie, cu atât mai mult de către ceilalți membrii ai parohiei. De aici revine și responsabilitatea preotului de a le a reaminti credincioșilor responsabilitatea lor ca „mădulare ale

\footnotetext{
${ }^{4}$ Paul Meyendorff, Taina Sfântului Maslu, trad. Cezar Login, Cluj-Napoca, Editura Renașterea, 2011, p. 75.
} 
Trupului lui Hristos" - Biserica față de toți ceilalți și mai ales față de cei bolnavi.

Aspectul comunitar al Tainei Maslului este decisiv în înţelegerea naturii sale autentic sacramentalo-eclezială. Faptul acesta transpare din chiar rânduiala Tainei ${ }^{5}$. Importantă la Taina Sfântului Maslu nu este atât tămăduirea prin ungere cu untdelemn de bolile trupeşti (aspectul fizic), cât reintegrarea celui aflat în suferinţă în comunitatea membrilor Trupului lui Hristos, cu regăsirea plinătăţii sfinţitoare (aspectul duhovnicesc). Pe de o parte, ,prin această Taină, Biserica ajută pe credincioşi să se comporte ca membri ai Trupului Domnului şi în situaţ̧ia de bolnavi. Din Hristos cel răstignit primitorii Tainei iau puterea să-şi poarte şi ei crucea suferinţelor lor trupeşti cu răbdarea uşurată de bucuria învierii lui Hristos care îi va învia şi pe ei. Răbdarea bărbătească susţinută de nădejdea învierii mobilizează forţele trupului care, ajutate de harul de sus, pot să aducă sănătatea, sau dacă voia lui Dumnezeu este alta, îi dau bolnavului linişte şi împăcare în faţa obştescului sfârşit". Pe de altă parte, aceasta evidenţiază aspectul eclezial comunitar al acestei Taine. Astfel este depăşită concepția romano-catolică despre Maslu ca extrema unctio, căci simultan cu recunoaşterea Bisericii ca o comunitate eshatologică ce are puterea care triumfã asupra morţii trebuie afirmată şi ungerea eclezială ca părtăşia Bisericii la suferinţa creştinilor bolnavi'.

\footnotetext{
${ }^{5}$ Dumitru Gh. Radu, Caracterul ecleziologic al Sfintelor Taine şi problema comuniunii, în „Ortodoxia”, nr. 1-2 (1978), p. 308: „Taina este săvârşită de şapte preoţi după numărul darurilor Duhului, rânduiala Tainei cuprinzând, de altfel, şapte Evanghelii şi rugăciuni pentru tămăduirea celui bolnav, pentru iertarea păcatelor şi mântuirea lui. De faţă se află o asistenţă împreună-rugătoare de credincioşi cu preoţii, miniştrii Tainei”".
}

${ }^{6}$ Ibidem, p. 307. 


\section{Vindecare și sfințire în Sfintele Taine}

Întreaga realitate eclezială exprimă plenitudinea vieţii mântuitoare a lui Iisus Hristos. Această ideea constituie punctul central al studiului Părintelui Profesor Ioan Ică, „Modurile prezenţei personale a lui Iisus Hristos şi ale comuniunii cu El în Sf. Liturghie şi Spiritualitatea ortodoxă" ", în care sunt depăşite extremele obiectivsubiectiv, sacramental-ascetic şi comunitar-individual prin afirmarea categorică a diverselor moduri de prezenţă (şi împărtăşire) a lui Hristos în Biserică: pe lângă cel euharistic-sacramental, la Liturghie se mai enumeră şi în locaşul bisericesc, în icoane, în cuvânt (predică şi lecturile biblice), rugăciuni şi cântări, totul susţinut şi valorificat printr-o suş̧inută lucrare ascetică şi filocalică (metanoia) de purificare şi urcuş duhovnicesc neîncetat. Astfel are loc o împărtăşire tainic-sacramentală şi duhovnicească cu Hristos care este în acelaşi timp şi o împărtăşire eshatologică de Hristos, o anticipare (arvună) a comuniunii depline şi fără sfârşit cu El în Împărăţia ce va să vină̊

Biserica se constituie ca Trup al lui Hristos cu multe mădulare ce ţin de acelaşi Cap şi care vizează în întregime viaţa Acestuia, ca o comunitate sobornicească şi sacramentală plină de Duhul lui Hristos, în şi prin Sfintele Taine (şi în special în şi prin Sfânta Euharistie). Prin urmare, „Tainele sunt împărtăşiri ecleziale de viaţă dumnezeiască din Hristos, celor ce se încorporează prin ele în Hristos sau odată încorporaţi în El ca mădulare ale Trupului Său, Biserica, cred în Hristos". Procesul este dublu: Hristos sălăşluieşte în noi

\footnotetext{
${ }^{7}$ Ioan Ică, Modurile prezenţei personale a lui Iisus Hristos şi ale comuniunii cu El în Sf. Liturghie şi Spiritualitatea ortodoxa, în Persoană şi Comuniune. Prinos de cinstire Pr. Prof. Acad. Dumitru Stăniloae (1903-1993), Sibiu, Editura Arhiepiscopiei ortodoxe, 1993, pp. 335-358.

${ }^{8}$ Vezi Ibidem, p. 355.

${ }^{9}$ Dumitru Gh. Radu, Caracterul ecleziologic al Sfintelor Taine şi problema comuniunii, în „Ortodoxia”, nr. 1-2 (1978), p. 18-19. Şi iarăşi: „Toate Tainele sunt relaţii personale cu Hristos în Biserică şi o continuă şi multiplă dăruire a
} 
prin harul împărtăşit de Duhul Sfânt în Sfintele Taine ale Bisericii, ia chip (formă) în noi, iar noi ne configurăm după chipul lui Hristos, ajutaţi de Acelaşi Duh Sfânt. În cel mai deplin sens al cuvântului comuniunea omului cu Dumnezeu şi actele prin care are loc această comuniune reprezintă o taină. Nu întâmplător Biserica şi-a (auto) definit Tainele sale ca ţinând de „simbol” - un termen care uneşte două realităţi „,numai aparent despărţite: o realitate vie care participă la o altă realitate vie sau unită cu ea care îi este celei dintâi absolut necesară pentru existenţă şi desăvârşire"10. Prelungirea Tainei lui Hristos, întemeiată pe baza tuturor actelor Întrupării, începând de la Bunavestire şi până la Înălţare, în comunitatea eclezială face ca Biserica însăşi să fie o taină, un sacrament ${ }^{11}$.

Lucrarea taumaturgică a Bisericii nu se epuizează în Taina Maslului - deși, nu este mai puțin adevărat, această taină este în special coroborată cu vindecarea trupească și sufletească a credincioșilor. Toate lucrările Bisericii - Taine și ierurgii - conferă harul sfințitor și vindecător, ajutându-l pe credincios să înainteze pe calea mântuirii (epectază).

După cum s-a văzut, imaginea Bisericii ca Trup al lui Hristos, în care credincioşii sunt mădulare, implică în mod absolut necesar și cerința ca, în cazul în care un mădular se îmbolnăvește, celelalte să încerce să-1 vindece sau, dacă nu este posibil, măcar să fie alături de el în vremurile grele. Astfel, Biserica este prin excelență mediul vindecării. Toate Tainele sale posedă o trăsătură taumaturgică (Paul Meyendorff insistând în special pe Tainele de inițiere: Botez, Mirungere și Euharistie $)^{12}$. Mai mult chiar, fiecare aspect al vieții

lui Hristos în Duhul Bisericii, luată ca întreg, ca trup al Său, cu multe mădulare, şi fiecărui mădular în parte care participă la viaţa lui Hristos în Biserică şi se împărtăşeşte cu unele sau cu mai multe din Tainele Bisericii”. Ibidem, p. 21.

${ }^{10}$ Ibidem, p. 25.

${ }^{11}$ Ibidem, p. 63.

${ }^{12}$ P. Meyendorff, op. cit., p. 30: „Orice rânduială sacramentală face referire la vindecare". 
Bisericii și al vieții membrilor săi implică un element tămăduitor. Viața liturgică, exprimată în Taine (o poziție specială în acest sens ocupând, bineînțeles, Taina Sfântului Maslu, n.n.), în ciclurile zilnic, săptămânal şi anual de rugăciune, dar și rugăciunile individuale ale fiecărui creștin, sun părți ale misiunii tămăduitoare a Bisericii. Și aceasta datorită faptului că vindecarea se găsește în chiar centrul misiunii Bisericii de a vesti Evanghelia"13.

\section{Sfânta Euharistie sau ,frângerea pâinii”}

Influenţa Sfinţilor Apostoli în secolul întâi care le poartă de altfel şi numele, s-a resimţit pretutindeni în spaţiul creştin; Sfinţii Apostoli şi mai apoi Părinţii apostolici au înţeles Sfintele Taine (chiar dacă acest termen dogmatic de taină avea să fie adoptat mult mai târziu în Biserică, cca. sec. al XI-lea) ca şapte mlădiţe vii prin care omul intră în legătură de viaţă cu butucul viei, cu Mântuitorul Hristos, ,fără de care nu putem face nimic"(Ioan 15, 17); ca şapte raze şi revărsări de lumină prin care primim darurile Duhului Sfânt (Isaia 11, 2-3); ca şapte izvoare drin care curge ,apa vieţii" a harului dumnezeiesc în sufletele noastre (Ioan 4, 10-14). „Didahia” denumeşte Sfintele Taine ca semne ale adevărului, ele deschizând omului cerul. Însemnătatea deosebită a Sfintelor Taine este tot una cu însemnătatea harului dumnezeiesc. Folosul Sfintelor Taine este tot una cu folosul pe care-1 avem din pricina harului. „Prin har suntem mântuiţi” scrie Sfântul Apostol Pavel (Efeseni 2, 5-8). Harul întăreşte firea omului spre bine şi-i dă sănătate sufletească, îi dă putere, să facă binele şi să învingă răul. Fără ajutorul harului vedem binele, dar facem răul (Romani 7).

Importanţa şi valoarea Sfintelor Taine în general şi al Spovedaniei și Euharistiei în special sunt comparabile în viaţa

${ }^{13}$ Ibidem, p. 34. 
Parohia, mediu de vindecare a creștinilor...

organică cu sângele ce pulsează în vinele fiecăruia dintre noi, sânge care ne face vii şi capabili de rod. Importanţa şi valoarea lor nu se poate dezvălui însă, în mod deplin, prin mijlocirea cuvintelor, ci numai prin trăirea nemijlocită şi practicarea permanentă a lor, prin împărtăşirea cu puterea transfiguratoare a harului divin ce se revarsă din ele şi aceasta în strânsa comuniune a credinţei, a nădejdii şi a dragostei cu celelalte mlădiţe ale trupului tainic al Mântuitorului.

Mântuitorul nu instituie nu numai taina Sfintei Euharistii fundamentul liturghiei creștine - ci şi celelalte taine de căpetenie ale vieţii creştine: botezul $(, \ldots$ mergând, învăţaţi toate neamurile, botezându-le..." Matei 28, 19), preoţia şi pocăinţa (Matei 28, 18; Ioan 20, 20-23: „Luaţi Duh Sfânt; cărora veţi ierta păcatele se vor ierta şi cărora le veţi ţine, ţinute vor fi” ). Unele forme secundare ale cultului provin de la Mântuitorul, Care le-a practicat şi le-a recomandat ucenicilor: binecuvântarea poporului prin ridicarea şi punerea mâinilor, binecuvântarea copiilor, cântarea de imne ş. $\mathrm{a}^{14}$. Dacă Sfântul Botez este ,poarta” de intrare a creştinilor în Biserică şi taina care uneşte pe toţi în Trupul lui Hristos, Sfânta Euharistie este „hrana” acestui Trup tainic, este „,doctoria nemuririi" ${ }^{15}$.

După ce la Cincizecime Biserica ia fiinţă ca instituţie teandrică, cel dintâi act teandric pe care îl trăieşte este săvârşirea primei Euharistii de către Apostoli şi împărtăşirea lor şi a primilor creștini cu Trupul şi Sângele Domnului. În Sfânta Euharistie se realizează unirea tuturor credincioşilor cu Hristos, dar şi unirea între toţi membrii Bisericii. Sfântul Ioan Hrisostom învaţă că toţi aceia care se împărtăşesc cu Hristos devin un singur trup, pentru că toţi se unesc cu Hristos şi toţi sunt părtaşi lui Hristos în egală măsură ${ }^{16}$.

${ }^{14}$ Pr. Prof. Ene Branişte, Liturgica specială, Bucuresti, Editura Lumea Credinţei,
ediţia a IV-a, 2005, p. 14 .
${ }^{15}$ Doctorand Leon Gh. Arion, Unitatea şi universalitatea Bisericii după
Epistolele pauline, în, ,Studii Teologice”, seria a II-a, anul XIX, nr. 1-2, ianuarie-
februarie, Bucureşti, 1967, p. 53 .
${ }^{16}$ Pr. Drd. Alexandru Tudor, Viaţa sacramentală a Bisericii în Faptele 
Referindu-se la aspectul comunitar al Sfintei Euharistii, Sfântul Luca aminteşte de câteva ori despre frângerea pâinii. Despre comunitatea creştină din ziua Cincizecimii (Fapte 2, 46-47), despre Sfântul Pavel care ajunsese în Troa, în cea de a treia călătorie misionară (Fapte 20,7-11), tot despre Sfântul Pavel care înainte de a coborî din corabie pentru a debarca pe insula Malta, îndeamnă pe toţi vieţuitorii să mănânce şi totodată încurajându-i că nici unul dintre ei nu va pieri (Fapte 27, 33-38) ${ }^{17}$.

Din vechime avem mărturii că laicii primeau Sfânta Împărtăşanie numai din mâna sfinţiţilor slujitori. Pentru că Sfânta Euharistie este o taină sfântă, atunci e de la sine înţeles că nu poate fỉ săvârşită decât de episcopi sau de preoţi, deoarece numai ei sunt „administratorii tainelor" (I Corinteni 4, 1; Efeseni 4, 11; I Corinteni 12, 28-30). Nici nu ne putem închipui posibilitatea de a împărtăşi altcineva decât preoţii această sfântă taină, câtă vreme este vorba de prefacerea pâinii şi a vinului în Trupul şi Sângele Mântuitorului, pentru iertarea păcatelor şi de o jertfă atât de înfricoşată ${ }^{18}$.

Împărtăşirea este ,piscul cel mai inalt al vieţii duhovnicești”" de aceea, se pot împărtăşi numai credincioşii pregătiţi şi vrednici de a primi Trupul şi Sângele Domnului, verificaţi ca atare de către duhovnic, prin spovedanie (I Cor. 11, 28-29). Se pare că primii creştini se împărtăşeau zilnic (Fapte 2, 42, 46). Mai târziu, răcindu-se zelul creştinilor, dar şi crescând respectul lor pentru Sfânta Împărtăşanie, numărul celor ce se apropiau de Sfântul Trup şi Sânge a început să se micşoreze treptat şi împărtăşirea lor s-a făcut din ce in ce mai rar ${ }^{20}$.

În concluzie se poate afirma că în Biserica primară, toţi creştinii,

Apostolilor, în „Studii Teologice”, seria a II-a, anul XXXII, nr. 1-2, ianuariefebruarie, Bucureşti, 1980, p. 201.

${ }^{17}$ Ibidem.

${ }^{18}$ Pr. Ion Cârciuleanu, Adevăruri creştine, Iasi, Editura Pim, 2003, p. 178.

${ }^{19}$ Pr. Florin Botezan, Spre tămăduirea sufletului şi a trupului, disponibil la adresa de web http://www.dervent.ro/resurse/liturghia/index-D-42.html.

${ }^{20}$ Pr. Prof. Ene Branişte, op. cit., p. 321. 
fără deosebire, petreceau necontenit într-un cuget în, frângerea pâinii", (Fapte 2, 42) sau, cum se spune ceva mai departe: ,Şi frângând pâinea în casă, luau împreună hrana întru bucuria şi curăţia inimii"” (Fapte 2, 46); adică se împărtăşeau cu ,pâinea şi vinul euharistic". Sfânta Euharistie a fost şi este actul divin care face din cei mulţi un singur trup şi un singur suflet, iar primii creştini au înţeles în chip desăvârşit şi au trăit cu intensitate acest mare adevăr ${ }^{21}$.

\section{Parohia și ortopraxia}

În textul de la Iacov $(2,26)$ se subliniază interdependența celor doi termeni: credinţa fără fapte este moartă, în sensul în care credinţa se exprimă prin fapte. Altfel spus, ortopraxia înseamnă viețuirea adecvată, aplicarea corectă în practică a unei învățături de credință autentic ortodoxe. Dreapta mărturisire şi preamărire a lui Dumnezeu necesită şi slujirea aproapelui şi a lumii, căci faptele întăresc credinţa omului, o argumentează şi-i descoperă finalitatea. De aceea Judecata de Apoi va viza deopotrivă credința și faptele omului.

Cunoaşterea adevărului dumnezeiesc este cunoaşterea vieţii celei adevărate. Adevărul credinței creştine este adevărul comuniunii personale şi al vieţii adevărate. În felul acesta, credinţa, care începe de la recunoaşterea datelor istorice ale descoperirii lui Dumnezeu, duce la experienţa duhovnicească a prezenţei Lui. Înţelegem acum nu doar că în legătura omului cu Dumnezeu e necesară credinţa, ci şi faptul că aceasta din urmă creează o nouă formă de cunoaştere o cunoaştere ce depăşeşte dimensiunea intelectuală şi se dezvoltă la nivelul libertăţii Duhului ca o comuniune existenţială.

Credinţa fără fapte este moartă, în sensul în care credința se exprimă prin fapte (vezi Iacov 2, 26). Faptele exprimă credinţa, în timp ce credinţa adevereşte faptele. Trebuie respinse deopotrivă

${ }^{21}$ Pr. Drd. Alexandru Tudor, art. cit., pp. 203-204. 
opiniile care socotesc că mântuirea poate surveni şi fără împlinirea poruncilor, exclusiv din credinţă, la fel cum trebuie respinsă şi ideea că faptele în sine sunt garanţia accederii la Împărăţia lui Dumnezeu, ca o plată datorată. Este adevărat că mântuirea sau pierderea omului depind de credinţa sau necredinţa acestuia în Hristos, care 1-a răscumpărat şi îndreptat pe om prin întrupare, viaţă de jertfă, moarte pe cruce, înviere şi înălţare. Pe de altă parte, faptele bune nu trebuie neglijate; ele nu reprezintă mijloace de răscumpărare a mântuirii, ci expresia firească a credinței. Nu este cu putinţă a crede în Dumnezeu şi în acelaşi timp a-ţi urî sau a-ţi neglija aproapele; măsura iubirii aproapelui, după modelul lui Dumnezeu, Care Îşi iubeşte toate făpturile, arată şi măsura credinţei. În fine, nu trebuie uitat că nu faptele în sine sunt meritorii. Dumnezeu nu cere omului doar fapte, ci şi intenţii generoase şi bunăvoinţă; faptele omeneşti sunt apreciate de El în funcţie de intenţia şi scopul omului ${ }^{22}$.

Mitr. Timiadis sublinia următorul aspect: ,Activitatea pastorală nu are ca principal obiect acele suflete care sunt schimbate de către lume, ci pe acelea care nu sunt capabile să schimbe lumea”. Ele sunt vindecate, şi apoi sunt şi capabile să vindece alte suflete. Aflate într-o relaţie de pace şi de reconciliere cu Dumnezeu, ele pot să-i pacifice şi să-i reconcilieze şi pe alţii cu Dumnezeu. De la comuniunea lor cu Sfântul Duh ei primesc înţelepciunea şi luciditatea de a vedea nu doar greşelile şi erorile din jurul lor, ci, de asemenea, şi nenumăratele binecuvântări şi posibilităţi pentru dragoste şi prietenie. Ele nu sunt atrase de soluţii filozofice, nici nu sunt dornice să introducă schimbări conceptuale, revoluţionare sau exterioare. Ele ştiu că întreaga dramă umană se petrece în noi înşine. Ele ştiu că nu este suficient să atingi răul cu superficialitate, ci că împotriva acestuia trebuie dusă o bătălie serioasă, pentru a-1 curăţa şi vindeca. Au învăţat din parohie că

${ }^{22}$ A se vedea mai ales Georgios I. Mantzaridis, Morala creştină II: Omul şi Dumnezeu; Omul şi semenul; Poziţionări şi perspective existenţiale şi bioetice, trad. Cornel Constantin Coman, Bucuresti, Edit. Bizantină, 2006, pp. 153-162. 
puterea lor nu constă în simple citiri necalificate din Biblie, sau în studiu teoretic în grup; ci că izvorul puterii lor şi a zelului lor pentru evanghelizare se află în Euharistie, cu care îşi identifică întreaga lor fiinţă. Ori de câte ori apare nevoia de comuniune-frăţietate, aceasta nu se datorează unei simple dorinţe lumeşti de apropiere socială. Comuniunea constituie un element extrem de necesar în natura fiecărei parohii, căci ea ne ţine uniţi organic şi în interdependenţă. Este Trupul viu al lui Hristos care se simte solidar, în care fiecare membru îşi asumă datoria de a construi întregul, grija pentru siguranţa, starea bună şi dezvoltarea normală a celorlalţi. Solidaritatea nu ar trebui să fie văzută atât în termenii asistenţei materiale asigurată de Biserică, ci într-o compasiune adâncă şi mutuală pentru fiecare membru al Bisericii, ca să fie adus cât mai aproape de Hristos. Viaţa este plină de capcane, calea vieţii este plină de curse, iar călătoria devine cu mult mai grea fără compania altor călători sau co-luptători. Prezenţa acestora aduce bucurie, încurajare, perseverenţă, călătoria devenind mult mai stimulativă’’23.

Mântuitorului Iisus Hristos a atenţionat că cei ce Îi urmează vor fi cunoscuți după roadele lor; a merge pe „calea lui Hristos” ca și creștin înseamnă a fi un exemplu de abnegație și slujire; faptele creștinilor sunt cele care depun cel mai mult mărturie despre Hristos și misiunea Lui transmisă tuturor creștinilor, deopotrivă clerici și laici. În actualul context socio-istoric globalizat și globalizant, ortodocșii sunt chemați să arate „comoara” lor - ortodoxia unită cu ortopraxia - la nivelul cel mai concret al existenței lor, exprimat la nivel eclezial de parohie. A fi aproape de cei bolnavi dintre ortodocși poate constitui prilejul unei mai strânse apropieri și de ceilalți din jur care nu sunt ortodocși, mai ales că într-o situație dificilă cunoașterea lui Dumnezeu poate căpăta alte dimensiuni. În acest sens, reflecțiile celui mai important teolog ortodox român din sec. XX, Dumitru Stăniloae, despre „cunoașterea lui Dumnezeu în împrejurările concrete ale vieții”, devin elocvente:

${ }^{23}$ Mitr. E. Timiadis, op. cit., pp. 277-278. 
această cunoaștere ține de viața practică și îl relevă pe Dumnezeu în lucrarea Sa providențială; fiecare om descoperă în împrejurările particulare ale vieții sale planul special al lui Dumnezeu cu el. „Fiecare Îl cunoaște în mustrările conștiinței pentru relele săvârșite; ... Îl cunoaște în necazurile, în insuccesele mai trecătoare sau mai îndelungate, în bolile proprii sau ale celor apropiați, ca urmări ale nor rele săvârşite sau ca mijloace de desăvârșire morală, de întărire spirituală ...”. Avem de-a face cu o cunoaștere ,palpitantă, apăsătoare, dureroasă, care trezește în ființa noastră responsabilitatea și încălzește rugăciunea și care o face să se strângă mai mult lângă Dumnezeu"24.

\section{Încheiere}

La finalul acestui studiu se cuvine să reamintim încă o dată imaginea pe care o adus-o în prim plan un teolog grec contemporan: acesta se referea la parohie ca la un „spital duhovnicesc”, a cărei înţelegere stă sub semnul unui singur scop, unic şi invariabil: îndumnezeirea (theosis) membrilor ei ${ }^{25}$. Viziunea ortodoxă proclamă viaţa creștină deopotrivă ca o ,învăţătură” (mathema) şi o ,pătimire” (pathema), deci ca un mod de vieţuire revelat, prin Intrupare, drept „,vestea cea nouă” (vezi Gal. 2,20: „Nu mai trăiesc eu, ci Hristos trăieşte în mine"). A vorbi despre mântuire este echivalent cu exprimarea unei angajări în procesul de tămăduire, de vindecare a existenţei umane, iar Sfinţii Părinţii au numit acest proces asceză. Acest proces nu avea însă doar un sens individual, ci pe deplin comunitar: privind mântuirea ca o ,vindecare” (therapeia), o conduită terapeutică corespunzător, trebuie ca inima „să se curăţească” (elibereze) de patimi ca să poată

${ }^{24}$ Dumitru Stăniloae, Teologia dogmatică ortodoxă, vol. 1, Ediţia a II-a, Bucuresti, EIBMBOR, 1997, p. 99.

${ }^{25}$ Gheorghios D., Metallinos, Parohia - Hristos în mijlocul nostru, trad. Ioan I. Ică, Sibiu, Edit. Deisis, 2004, p. 23. 
fi luminată de Duhul Sfânt. Desăvârșirea fiecărui credincios în parte trimite la dimensiunea existenţei în cadrul Bisericii, căci cel unit cu Dumnezeu şi umplut de harul dumnezeiesc necreat poate, ,să-i iubească cu adevărat (dezinteresat) pe toţi semenii, lui confraţi în umanitate şi să creeze împreună cu ei o comunitate autentică şi curată" ${ }^{26}$.

În fapt, comunitatea aceasta este chiar Biserica, Trupul viu al lui Hristos zidit din mădulare multiple supuse procesului de vindecare, adică de restaurare a sănătăţii noastre duhovniceşti. Climat unui astfel de proces îl asigură parohia: un loc de vindecare şi restabilire a omului întreg, un ,spital duhovnicesc” în care omul renăscut prin Tainele de iniţiere este capabil să trăiască într-o viaţă şi comunitate nouă ce are ca centru pe Hristos. Şi doar având drept „,cap” pe Hristos viaţa credinciosului se poate transforma harismatic în rugăciune, mulţumire, doxologie ${ }^{27}$.

\section{Bibliografie}

1. Tudor, Alexandru, Viaţa sacramentală a Bisericii în Faptele Apostolilor, în „Studii Teologice”, seria a II-a, anul XXXII, nr. 1-2, ianuarie-februarie, Bucureşti, 1980.

2. Timiadis, Emilianos, Preot, parohie, înnoire. Noțiuni și orientări pentru teologia și practica pastorală, trad. Paul Brusanowski, București, Edit. Sophia, 2001.

3. Dumitru, Gh. Radu, Caracterul ecleziologic al Sfintelor Taine şi problema comuniunii, în „Ortodoxia”, nr. 1-2, 1978.

4. Stăniloae, Dumitru, Teologia dogmatică ortodoxă, vol. 1, Ediţia a II-a, Bucureşti, EIBMBOR, 1997.

5. Branişte, Ene, Liturgica specială, ediţia a IV-a, Bucureşti, Editura Lumea Credinţei, 2005.

6. Botezan, Florin, Spre tămăduirea sufletului şi a trupului, disponibil la adresa de web http://www.dervent.ro/resurse/

\footnotetext{
${ }^{26}$ Ibidem, p. 24.

${ }^{27}$ Ibidem, p. 25.
} 
liturghia/index-D-42.html.

7. Mantzaridis, Georgios I., Morala creştină II: Omul şi Dumnezeu; Omul şi semenul; Poziţionări şi perspective existenţiale şi bioetice, trad. Cornel Constantin Coman, Bucureşti, Edit. Bizantină, 2006.

8. Metallinos, Gheorghios D., Parohia - Hristos în mijlocul nostru, trad. Ioan I. Ică, Sibiu, Edit. Deisis, 2004.

9. Ică, Ioan, Modurile prezenţei personale a lui Iisus Hristos şi ale comuniunii cu El în Sf. Liturghie şi Spiritualitatea ortodoxă, in Persoană şi Comuniune. Prinos de cinstire Pr. Prof. Acad. Dumitru Stăniloae (1903-1993), Sibiu, Editura Arhiepiscopiei Ortodoxe, 1993.

10. Cârciuleanu, Ion, Adevăruri creştine, Iaşi, Editura Pim, 2003.

11. Larchet, Jean-Claude, Teologia bolii, trad. Vasile Mihoc, Sibiu, Editura „Oastea Domnului”, 1997.

12. Arion, Leon Gh., Unitatea şi universalitatea Bisericii după Epistolele pauline, în „Studii Teologice”, seria a II-a, anul XIX, nr. 1-2, ianuarie-februarie, Bucureşti, 1967.

13. Meyendorff, Paul, Taina Sfântului Maslu, trad. Cezar Login, Cluj-Napoca, Editura Renașterea, 2011. 